\title{
THE DEMISE OF IN PARI DELICTO IN PRIVATE ACTIONS PURSUANT TO REGULATORY SCHEMES
}

In Perma Life Mufflers, Inc. v. International Parts Corp. ${ }^{1}$ the United States Supreme Court abolished the doctrine of in pari delicto ${ }^{2}$ in private antitrust actions. The reason for the Court's decision was one of policy: when a regulatory scheme relies, in part, upon private action for enforcement, the private action should be denied only if it fails to effectuate the regulatory policies and purposes. ${ }^{3}$ Thus, a private antitrust action will be allowed if it helps achieve free competition, the primary purpose of the antitrust statutes. ${ }^{4}$ In pari delicto, which examines the relative conduct of the parties as a possible bar to the private action, is not only irrelevant to this determmation; it actually inhibits private actions and thereby frustrates the effectuation of regulatory policies. ${ }^{5}$ The Supreme Court's intent is clear: the private action should be viewed as a tool for achieving enforcement and not as a means by which a culpable plaintiff might wrongly profit.

While Perma Life's significance for antitrust law is apparent, there has been confusion over its pertinence to private actions in securities law, another regulatory endeavor. The argument in favor of applying

1. 392 U.S. 134 (1968).

2. "In pari delicto," which literally means "equal fault," is an equitable defense judicially invoked to bar a plamtiff's action. It applies to illegal conduct in which both parties are equally or mutually mvolved. $1 \mathrm{~J}$. POMEROY, EQUITY JURISPRUDENCE 942 (5th ed. 1941). See Comment, Limiting the Unclean Hands and In Pari Delicto Defenses in Anti-trust Suits: An Additional Justification, 54 Nw. U.L. Rev. 456, 456 (1959). The doctrine derives from the principle "In pari delicto porior est conditio defendentis": "In a case of equal or mutual fault the condition of the party defending is the better one." Black's Law Dictionary 898 (rev. 4th ed. 1968). The defense is primarily based on the court's unwillingness to be used as a tool of the wrongdoer and on the principle that a wrongdoer should not be able to profit from his wrongdoing. Sce Perma Life Mufflers, Inc. v. International Parts Corp., 392 U.S. 134, 151 (1968) (Marshall, J., concurring in the result); Note, In Pari Delicto and Consent as Defenses in Private Antitrust Suits, 78 HARV. I. REv. 1241, 1242 (1965).

The defense was first recognized in an antitrust action in Bishop v. American Preservers Co., 105 F. 845 (N.D. IIl. 1900).

3. See J.I. Case Co. v. Borak, 377 U.S. 426, 433 (1964).

4. In United States v. Colgate \& Co., 250 U.S. 300, 307 (1919), Mr. Justice McReynolds noted:

The purpose of the Sherman Act is to prohibit monopolies, contracts and conbinations which probably would unduly interfere with the free excrcise of their rights by those engaged, or who wish to engage, in trade and commercein a word to preserve the right of freedom to trade.

Accord, Paramount Famous Corp. v. United States, 282 U.S. 30, $42-43$ (1930); United States v. American Linseed Oil Co., 262 U.S. 371, 376 (1923); Ramsay Co. v. Bill Poster's Ass'n, 260 U.S. 501, 512 (1922).

5. See text accompanying note 27 infra. 
Perma Life is that policy decisions regarding the public interest nature of private actions in one regulatory scheme pertain to private actions vindicating similar interests in another despite structural differences between them. ${ }^{6}$ The private securities-action cases that have considered Perma Life ${ }^{7}$ strongly suggest that its mandate must be considered.

This Comment analyzes four private securities law cases $^{8}$ to determine the proper application of the Perma Life inandate to securities law. It then considers the possibility of applying Perma Life to private actions under one aspect of California's securities regulation. Underlying this analysis is the judicial philosophy reflected in Perma Life and the historical context in which the case arose.

\section{The Perma Life Philosophy}

Perma Life was brought by four Midas Muffler dealers against their franchisor, ${ }^{9}$ alleging that certain provisions of the franchise contract violated the antitrust laws. Pursuant to the defendants' plan to establish a nationwide chain of franchise dealers, the parties had entered into an agreeinent whereby the plaintiffs received exclusive territorial rights and Midas agreed to underwrite the cost of a lifetime guarantee for the mufflers. The plaintiffs agreed to sell only Midas products at prices determimed by Midas, to buy parts only from Midas, to deal only in exhaust parts, and to open ncw locations only with the consent of Midas. The plaintiffs, although earning lucrative profits, tried unsuccessfully to eliminate the onerous restrictions, but Midas refused

6. Given antitrust's treble damage provision, the public interest is arguably greater in antitrust than in securities law. However, such an argument fails to account for at least part of the motivation behind the treble damage provision: to offset the potential plaintiff's fear of retribution from the defendant who is ofteu dealing in the same market. MacIntyre, The Role of the Private Litigant in Antitrust Enforcement, 7 ANTITRUST BULL. 113, 125 (1962). The plaintiff in a private securities action harbors no sucli fear.

7. Pearlstein v. Scudder \& German, 429 F.2d 1136 (2d Cir. 1970); Kuehnert v. Texstar Corp., 412 F.2d 700 (5th Cir. 1969); Nathanson v. Weis, Voison, Cannon, Inc., 325 F. Supp. 50 (S.D.N.Y. 1971); Serzysko v. Chase Manhattan Bank, 290 F. Supp. 74 (S.D.N.Y. 1968); Wohl v. Blair, 50 F.R.D. 89 (S.D.N.Y. 1970). For a general discussion of in pari delicto in securities, see Godfrey, Plaintiff's Conduct as a Bar to Recovery Under the Securities Acts: In Pari Delicto, 48 Texas L. Rev. 181 (1969).

8. The cases are those cited note 7 supra. Wohl, a $10 \mathrm{~b}-5$ action where the court denied recovery to an investor suing his broker for losses resulting from a "bad" tip, is not considered separately, however, since it simply reiterates Kuehnert's analysis and conclusions.

9. The complaint named as defendants six individuals and four corporations, includimg International Parts Corporation and Midas. 392 U.S. at 135. 
and threatened to terminate the agreements if they failed to comply. ${ }^{10}$ Subsequently, the agreements were terminated by Midas or by the plaintiffs themselves, ${ }^{11}$ and the suit was instituted. The plaintiffs claimed that the agreements constituted a conspiracy to restrain trade and lessen competition in violation of the Sherman and Clayton Acts. ${ }^{12}$

The defendants won a motion for summary judgment in the district court on the ground that plaintiffs, as signatories to an agreement that contaimed favorable as well as detrimental illegal clauses, were in pari delicto. ${ }^{13}$ The Seventh Circuit affirmed the judgment, noting that the plaintiffs had enthusiastically sought to acquire a Midas franchise with full knowledge of the provisions, had solemnly subscribed to the agreement, and, after making lucrative profits, had eagerly sought and voluntarily entered imto additional franchise agreements with the defendants. ${ }^{14}$ Justice Black, reversing for a majority of five, ${ }^{15}$ resolved the issue of plaintiffs' participation by abolishing the doctrine of in pari delicto as a defense to a private antitrust action. ${ }^{16}$

Although the plaintiffs recovered in Perma Life, the abolition of in pari delicto does not necessarily mean that all private actions are absolute. ${ }^{17}$ The franchisee plaintiffs in Perma Life were deemed to be less culpable than the defendant franchisor because the plaintiffs, whose bargaining positions were weaker, were coerced into accepting the entire scheme. ${ }^{18}$ In separately considering the equal fault ${ }^{10}$ sit-

10. Id. at 137.

11. The complaint alleged that one franchisee had his agreement cancelled by Midas when he purchased exhaust parts from an outside source, and that other plaintiff dealers had themselves cancelled their agreements. Id.

12. Sherman Act $\$ 1,15$ U.S.C. $\$ 1$ (1970); Clayton Act \$ 3, 15 U.S.C. \$ 14 (1970). The plaimtiffs also alleged price discrimination violating section $2(a)$ of the Clayton Act, as amended by the Robinson-Patman Act, 15 U.S.C. $\$ 13$ (1970).

13. Perma Life Mufflers, Inc. v. International Parts Corp., (1966 Trade Cas.) If 71,801, at 82,704 (N.D. I11. Feb. 25, 1966).

14. Perma Life Mufflers, Inc. v. International Parts Corp., 376 F.2d 692, 693-95 (7th Cir. 1967).

15. Justice Black was joined by Justices Douglas, White, Brennan, and Chief Justice Warren in the decision to abolish in pari delicto. Justices Marshall and Fortas concurred in the result on the ground that in pari delicto was misapplied in this case but advocated the retention of the defense. 392 U.S. at 147, 148. Justices Harlan and Stewart, concurring in part and dissenting in part, also expressed a desire to retain in pari dehicto and wanted the case remanded to the trial court for a more careful consideration of its application. Id. at 153.

16. Justice Black declared that the "doctrine of in pari delicto, with its complex scope, contents, and effects, is not to be recognized as a defense to an antitrust action." 392 U.S. at 140.

17. "Absolute action" means one that can be barred only on its substantive merits; there are no equitable limitations. If the substantive elements are present, plaintiff recovers. Throughout this discussion, reference to "absolute recovery" is meant to be synonomous with "absolute action."

18. 392 U.S. at 140. Justice Black did not believe the plaintiffs to be "truly and completely" involved with the defendants in the illegal agreements. He noted that the 
uation in dictum, Justice Black refused to decide whether recovery should be available when the plaintiff is "truly and completely involved." ${ }^{20}$ However, the Perma Life Court did develop a new formula applicable to all degrees of plaintiff involvement: in pari delicto has been rejected as a defense and recovery now rests on enforcement considerations. This new development constitutes the real source of controversy anong the justices. ${ }^{21}$ This approach was grounded in Justice Black's basic perspective that the judiciary should use all reasonable ineans to eliminate anticompetitive business conduct. ${ }^{22} \mathrm{He}$ inade no attempt in Perma Life to balance the competing interests of eliminating anticompetitive schemes and investigating the moral worth of the plaimtiffs. In his view, such balancing inhibits the effectiveness of the private action, which is the basis of antitrust enforcement. ${ }^{23}$

franchisees' participation "was not voluntary in any meaningful sense" because, although they enthusiastically sought the franchises as a whole, they "did not actively seek each and every clause," some of which were detrimental to their interests. Id. at 139. The franchisor was not sacrificing as much as the franchisees; the agreement was basically the product and design of the franchisor. Id. Justice Black's description of truly complete involvement-active support of the entire monopolistic scheme by participating in the formulation and encouraging its continuation [392 U.S. at 140] -implies a situation of truly equal fault. Justice Black apparently had in mind the situation where two competing manufacturers, in equal bargaining position, combine to fix prices.

19. Equal fault in the Perma Life context means truly equal fault. See note 18 supra.

20. They [the defendants] picture petitioners as actively supporting the entire restrictive program as such, participating in its formulation and encouraging its continuation. We need not decide, however, whether such truly complete involvement and participation in a monopolistic scheme could ever be a basis, wholly apart from the idea of in pari delicto, for barring a plaintiff's cause of action....

392 U.S. at 140.

21. See note 33 infra.

22. Public interest in the enforcement of the antitrust law is great, and the treble damage award can be viewed as an inducement to injured parties to brimg private actions. See generally Comment, Limiting the Unclean Hands and In Pari Delicto Defenses in Anti-trust Suits: An Additional Justification, 54 Nw. U.L. REv. 456 (1959); Note, In Pari Delicto and Consent as Defenses in Private Antitrust Suits, 78 Harv. L. Rev. 1241 (1965); Note, Unclean Hands: The Effect of Plaintiff's Antitrust Violations on Antitrust Actions, 113 U. PA. L. Rev. 1071 (1965). The legislative effort to create open competition has been characterized as nothing less than "a charter of freedom" to insure the individual has "right to freedom of trade." Yankwich, Competition, Real or Soft?, 14 F.R.D. 199, 202 (1953).

23. Justice Black argued:

We have often indicated the inappropriateness of invoking broad common-law barriers to rehef where a private suit serves important public purposes. . . . The plaintiff who reaps the reward of treble damages may be no less morally reprehensible than the defendant, but the law encourages his suit to further the overriding public policy in favor of competition. A more fastidious regard for the relative inoral worth of the parties would only result in seriously undermining the usefulness of the private action as a bulwark of antitrust enforcement.

392 U.S. at 138-39. 


\section{A. The Perma Life Situation: Unequal-Fault}

From its inception, the private treble damage action has been an integral part of the overall enforcement scheme, for it constitutes a strong deterrent to potential violators. ${ }^{24}$ And, in fact, the judicial invocation of the in pari delicto defense did not totally ignore the public interest manifested in the regulatory statute; on the contrary, in pari delicto was adopted im deference to regulatory policy since it requires an equal degree of fault rather than any amount of fault. By deliberately choosing in pari delicto over the "unclean hands" defense, ${ }^{25}$ the intent, and the effect, was to strengthen the private action. ${ }^{20} \mathrm{Nev}-$ ertheless, while in pari delicto requires a higher degree of culpability than "unclean lands" before an action is denied, its focus on the internal relationship of the parties reflects an unresolved conflict between the two competing policies mentioned above: judicial reluctance to aid an unconscionable plaintiff ${ }^{27}$ and the public interest in effectuating the regulatory policies.

Furthermore, judicial consideration of relative moral worth involves a case-by-case determination of what constitutes equal fault, and the amorphous quality of "equal fault" renders uniform application impossible. Therefore, even if it is assumed that a correct application of in pari delicto sufficiently vindictates the public interest, its discretionary application inevitably fosters inconsistency and undermines enforcement. ${ }^{28}$ At least for cases involving coercion, such as

24. See MacIntyre, The Role of the Private Litigant in Antitust Enforcement, 7 Antritrust Bull. 113, 114-15 (1962); Wham, Antitrust Treble-Damage Suits: The Government's Chief Aid in Enforcement, 40 A.B.A.J. 1061, 1062 (1954).

25. "Unclean hands" applies to generally unconscionable conduct. The plaintiff need not be involved in the defendant's violation. $2 \mathrm{~J}$. POMERoY, EQUITY JURISPRUDENCE 94, 137 (5th ed. 1941).

26. See Pennsylvania Water \& Power Co. v. Consolidated Gas Elec. Light \& Power Co., 209 F.2d 131 (4th Cir. 1953), cert. denied, 347 U.S. 960 (1954) (the clearest antitrust example). See also Can-Am Petroleum Co. v. Beck, 331 F.2d 371 (10th Cir. 1964) (securities law); Miller v. California Roofing Co., 55 Cal. App. 2d 136, 130 P.2d 740 (1st Dist. 1942) (securities law). Allowing a person with "unclean hands" to recover raises the threshold for denial to a higher degree of culpable conduct.

27. See note 2 supra.

28. Justice Black stated:

Although in pari dehicto hiterally means "of equal fault," the doctrine has been applied, correctly or incorrectly, in a wide variety of situations in which a plaimtiff seeking damages or equitable rehef is himself involved in some of the same sort of wrongdoing.

392 U.S. at 138. That discretionary application of in pari delicto produces different results can be illustrated by comparing the Perma Life decision in the circuit court [376 F.2d 692 (7th Cir. 1967)] with the view of the Supreme Court Justices who advocated the retention of in pari delicto and would have reversed the decision below on the basis that in pari delicto was misapplied. They emplrasized that the plaintiffs were not as responsible for the restrictive nature of the agreement because they were forced to accept all the provisions or forgo the business opportunity. 
Perma Life, Justice Black overcame these deficiencies of in pari delicto -incomplete deference to enforcement and the development of imconsistent case law-by making recovery absolute. ${ }^{29}$

\section{B. The Equal Fault Situation}

The significance of Perma Life's abolition of in pari delicto extends beyond the facts of the case. The plaintiffs in Perma Life were not equally at fault; therefore, a correct application of in pari delicto would also have reached the same result. ${ }^{30}$ To inake recovery absolute up to the point of "truly complete involvement" is conceptually identical to an in pari delicto approach that allows recovery up to equal fault.

Therefore, the ultimately more important aspect of Perma Life's abolition of im pari delicto is revealed in Justice Black's approach to the equal fault situation. An in pari delicto approach would auto-

\section{U.S. at 152, 156.}

For additional examples of conflicting results in the antitrust field, compare H \& A Selmer, Inc. v. Musical Instrument Exch., Inc., 154 F. Supp. 697 (S.D.N.Y. 1957); Louisiana Petroleum Retail Dealers, Inc. v. Texas Co., 148 F. Supp. 334 (W.D. La. 1956); Affiliated Music Enterprises v. Sesac, Iuc., 17 F.R.D. 509 (S.D.N.Y. 1955) with Pennsylvania Water \& Power Co. v. Consolidated Gas Elec. Light \& Power Co., 209 F.2d 131 (4th Cir. 1953), cert. denied, 347 U.S. 960 (1954); Trebuhs Realty Co. v. News Syndicate Co., 107 F. Supp. 595 (S.D.N.Y. 1952). For examples of conflictiug results in securities, see text accompanying notes 140-49 infra.

29. It is true that Justice Black directed some attention to the problem of unjustly enriching a plaintiff with treble damages in addition to the benefits received from the other provisions of a contract in which he fully participated. To mitigate this problem, he suggested a "damage-offset" method whereby those benefits accruing from provisions for which plaintiff was responsible are subtracted from the loss sustained due to the illegal provisions. 392 U.S. at 139-40. However, in concluding that "the possible beneficial by-products of a restriction from a plaintiff's point of view can of course be taken into consideration in computing damages . . " [392 U.S. at 140], the Court did not imply that any benefit resulting from an illegal restriction inust be subtracted. Such an interpretation would lead to the conclusion that a plaintiff would be demed recovery if the benefits realized equalled the losses, even though he did no more than assent to the agreement. Thus, the Supreme Court would have eliminated in pari delicto only to discourage a plaiutiff's action by allowing the defendant to incorporate enough beneficial clauses into the agreement to offset calculated losses. This would contradict the entire thrust of the opinion-that equity alone cannot be the basis for denying recovery. The damage-offset rule must be recognized as a method derived from the peculiar circumstances of a multiclause contract-a method of minimizing unjust enrichment to the plaintiff while simultaneously maximizing the effect provided by the encouragement of private actions. It is subordinate to and cannot displace the Court's enforcement perspective. Therefore, the proper approach appears to be that some of the inequity involved in awarding a wrongdoer treble damages can be alleviated without discouarging the private action, but the concern for unjust enrichment cannot be the determinative factor. Ultimately, recovery depends on enforcement considerations. But see Comment, In Pari Delicto: The Consumer's Best Friend, 30 OHIO ST. L.J. 332 (1969).

30. See the concurring opinions of Justices Marshall and Fortas, 392 U.S. at $147,148-49$. 
matically deny recovery in such cases, but by expressly refusing to rule whether recovery should issue where the plaintiff was equally at fault, "wholly apart from the idea of in pari delicto,"31 Justice Black implied that even here a new standard would be used for recovery. ${ }^{32} \mathrm{Al}$ though he did not specify the criteria for recovery in an equal fault situation, he clearly intended that recovery should depend on whether enforcement of the antitrust laws is effectuated. ${ }^{33}$ The thrust of Perma Life-that the public interest in eliminating anticompetitive schemes overrides consideration of the parties' relative worth ${ }^{34}$-means that recovery in an equal fault situation must also turn on enforcement considerations. $^{3 \mathbf{5}}$

31. 392 U.S. at 140.

32. Not only could Justice Black have grauted recovery by properly applying in pari delicto on traditional grounds; he could also have applied the recently articulated coercion exception in Simpson v. Union Oil Co., 377 U.S. 13 (1964). The Simpson rationale, similar to that adopted by the four Justices who advocated the retention of in pari delicto, is grounded in the notion that one who is coerced into an illegal scheme is not in pari dehicto.

Simpson involved gas and oil dealerships where the defendants distributed petroleum products to the plaintiff and controlled the leases on the land that the dealers used. The plaintiff had to agree to the monopolistic scheme or forgo the business opportumity. Simpson held the plaintiff not in pari delicto and granted recovery by broadly defining economic coercion as a loss of a desirable economic opportunity. 377 U.S. at 16. Similarly, in Perma Life Justice Black noted that the unequal bargaining position of a franchisee forces him to agree to restrictive covenants in order to receive the benefits of the business opportunity. Furthermore, he noted that the franchisee's participation was involuntary [see note 18 supra]. Thus, although the coercive elements were more blatant in Simpson, Simpson's definition of economic coercion is broad enough to cover the factual situation present in Perma Life. Therefore, Justice Black's broad holding eliminating relative moral worth as a condition for recovery must be considered a deliberate and purposeful decision to establish a new and imovative rationale.

33. The opinions of the four justices who rejected the sweeping abolition of in pari delicto further indicate that the defense was totally abohshed and replaced by the new enforcement standard. While they agreed with the majority that the plain. tiffs should recover on the facts [392 U.S. at 147, 151, 154], they disagreed with the implications of Justice Black's express disclaimer regarding equal fault-that a plaintiff equally at fault would presumably be allowed recovery if enforcement would be served. They argued that a court should consider the equities and deny any award to a plaintiff equally at fault. In the words of Justice Marshall:

The reasons I see for rejecting the approach taken by this Court are, perhaps, less related to the public interest in eliminating all forms of anticompetitive business conduct and more related to the equities as between the parties. The principle that a wrongdoer shall not be permitted to profit through his own wrongdoing is fundamental in our jurisprudence. The traditional doctrine of in pari delicto is itself firmly based on this principle.

392 U.S. at 151.

34. See note 23 supra.

35. Premier Elec. Constr. Corp. v. Miller-Davis Co., 292 F. Supp. 213 (N.D. Ill. 1968), rev'd, 422 F.2d 1132 (7th Cir. 1970) applied Perma Life to antitrust actions and demonstrated an awareness of Perma Life's sweeping holding that in pari delicto was totally abolished. The court ruled the plaintiff in pari delicto because, since he was the instigator, recovery would defeat enforcement of the law. Id. at 218 , 
Although recovery is not certain in equal fault situations, the enforcement standard requires that the court determine whether the threat of private enforcennent actually deters antitrust violations. Justice Black's desire to reserve judgment in equal fault situations can be explained by the uncertain deterrent effect of the threat. While the threat of private action in unequal fault situations is a viable ineans of promoting enforcement, the potential for both parties to sue in an equal fault situation seriously undermines deterrence because the eventual plaintiff is not known or predictable. ${ }^{36}$ Where both parties fully participate in the fornulation and continuation of the plan, it is more like the ordinary bargaming situation in which each party feels he has made a good deal and expects that, if dainages are suffered, the other party will be the injured party. The threat is thus much less certain and much less capable of producing effective deterrence. ${ }^{37}$

Unless the Supreme Court rules directly that competition is best served by allowing recovery in an equal fault situation, each court must determine on a case-by-case basis whether recovery will serve enforcement. ${ }^{38}$ But the resulting discretion operates only within the boundaries of the enforcement mandate: the conduct of the plaintiff cannot in and of itself result in rejection of his claim. Instead, enforcement is the standard, and the existence of a viable threat is the issue to be determined.

\section{II}

\section{Perma Life's Application to Securities LaW}

Securities transactions giving rise to alleged violations of securities regulations can be analogized to the equal fault rather than the unequal fault situation in antitrust. The securities transaction is

The court was using in pari delicto as a label for an enforcement determination. On appeal, the Seventh Circuit remanded [422 F.2d 1132 (7th Cir. 1970], deeming the facts insufficient to establish plaintiff as an instigator. $422 \mathrm{~F} .2 \mathrm{~d}$ at 1138.

36. A similar argument was made by Justice White, who concurred with Justice Black and three others in the abolition of in pari delicto. In a separate opinion he suggested that recovery should be decided under a "causation" formula, and he concluded that allowing an equally responsible plaintiff recovery would serve as a counterdeterrent and therefore should be deried. 392 U.S. at 146.

37. When an equal fault situation does arise, other enforcement factors, external to the parties' internal relationship, might be used to resolve the situation if the threat analysis proves inconclusive. Such enforcement criteria could include the exposure of illegal conduct of the parties to third parties who were unaware of their legal injury. Also, the assurance of consistent case law deserves some weight. See Kuehnert v. Texstar Corp., 412 F.2d 700, 706 (5th Cir. 1969) (dissenting opinion).

38. It should be clear that a court cannot allow recovery by simply characterizing the case to be one of unequal fault, without any regard to the enforcement issue. A finding of unequal fault by itself is not sufficient to satisfy Perma Life principlesthe existence of a viable threat must be ascertained to allow recovery. 
typically a single transaction; there is no complicated multiclause contract divisible into various beneficial and detrimental aspects. The securities cases discussed below have found Perma Life's approachbasing recovery on enforcement considerations--pertinent even in this equal fault situation. ${ }^{39}$ The propriety of using Perma Life in these cases depends on the efficacy of the threat in the particular regulatory scheme.

\section{A. Perma Life's Application to Margin Violations}

Serzysko v. Chase Manhattan Bank ${ }^{40}$ and Pearlstein v. Scudder \& German $^{41}$ have found Perma Life pertinent to margin violations. However, while the results on the facts of the two cases are reconcilable, their differences in perspective and in the treatment of the "threat" theory raise potential conflict. This reveals that the incorporation of the Perma Life enforcement mandate is not dispositive; differences may remain in the enforcement formula. Before considering the precise application of Perma Life in each case, a threshold issue must be recognized: what is the source of the private action and does it complement the purposes of the statutory scheme?

\section{Providing Perma Life With a Proper Foundation in Implied Mar- gin Actions ${ }^{42}$}

Under the margin rules, an implied action was originally available only to certain members of the investor class. The imphed remedy, conceived in Remar v. Clayton Securities Corp., ${ }^{43}$ is based on the statutory purpose ${ }^{44}$ to protect the unsophisticated investor. ${ }^{45}$ But the

39. Although Kuehnert v. Texstar Corp., 412 F.2d 700 (5th Cir. 1969), and its sequel, Wohl v. Blair, 50 F.R.D. 89 (S.D.N.Y. 1970), declined to recognize Perma Life's applicability, the following discussion of Kuelmert clearly demonstrates that it did, in reality, "recognize" Perma Life but that it feared its implications. See text accompanying notes 93-98 infra.

40. 290 F. Supp. 74 (S.D.N.Y. 1968).

41. 429 F.2d 1136 (2d Cir. 1970).

42. The margin statutes are unique in that they refer to a secondary purpose of protecting a certain class of investors-the "unsophisticated"-and the private action was first restricted to this class. Since the other private actions in the seeurities field are based on regulatory provisions that make no distinctions among investors, this discussion is not pertinent to $10 \mathrm{~b}-5$ or the express private action in California securities law.

43. 81 F. Supp. 1014 (D. Mass. 1949). For examples applying the Remar approach, see Reader v. Hirsch \& Co., 197 F. Supp. 111 (S.D.N.Y. 1961); Myer v. Shields \& Co., 25 App. Div. 2d 126, 267 N.Y.S.2d 872 (1st Dept. 1966).

44. Remar relied on the statutory tort doctrine, which implies an action to protect those members of a class for whom the statute was intended from the harm with which the statute was concerned. See RestatemENT OF ToRTS $\$ 286(c)$ (1934). This basis for implying civil remedies gives rise to several traditional tort concepts including contributory negligence and proximate causation.

45. Congressional desire to protect the unsophisticated investor was only inci- 
plaintiff investors participating in the violations in Serzysko and Pearlstein were experienced and sophisticated. Therefore, had Remar provided the only rationale for implying a private action, Perma Life could not apply, because the sophisticated investor is outside the class of investors to whoin Congress incidentally extended protection. However, both Serzysko and Pearlstein relied on the alternative rationale for implied actions articulated in J.I. Case Co. v. Borak ${ }^{46}$ to provide a foundation for Perma Life.

In Borak the Court reasoned that a private remedy should be implied when such a remedy is necessary to effectuate fully the statute's regulatory function. ${ }^{47}$ The conclusion that private actions aid enforcement is based on analogy to the role of the private action in antitrust:

Private enforcement of the proxy rules provides a necessary supplement to Commission action. As in an antitrust treble damage action, the possibility of civil damages . . . serves as a most effective weapon in the enforcement of the proxy requirements. ${ }^{48}$

Both Serzysko and Pearlstein relied on Borak and found the implied private action under the margin rules to be a "necessary supplement"40 to effectuate the statute's primary purpose of preventing excessive speculation, without regard to the investor's sophistication. Thus, once it is determined that an implied private action exists in the sophisticated-

dental; the primary purpose for initiating margin regulation was prevention of excess stock market speculation:

The main purpose is to give a Government agency an effective method of reducing the aggregate amount of the nation's credit resources which can be directed into the stock market and out of other more desirable uses of commerce and industry-to prevent a recurrence of the pre-crash situation where funds which otherwise would have been available at normal interest rates for uses of local commerce, industry, and agriculture, were drained by far higher rates into security loans and the New York Call Market.

H.R. REP. No. 1383, 73d Cong., 2d Sess. 8 (1934). This same report noted that "protection of the small speculator by making it impossible for him to spread himself too thinly ... will be achieved as a byproduct of the main purpose ...." Id. Mr. Thomas G. Corcoran, one of the drafters of the Exchange Act, agreed:

One is to protect the lamb; another, and probably the more important of the two .... is the protection of the national business system from the fluctuations that are induced by fluctuations in the market. . . .

Hearings on Stock Exchange Practices Before the Senate Comm. on Banking and Currency, 73d Cong., 1st Sess., pt. 15, at 6494 (1934). See generally Note, Federal Margin Requirements as a Basis for Civil Liability, 66 CoLum. L. REv. 1462 (1966). 46. 377 U.S. 426 (1964). The Court implied a private action for a violation of section 14(a) of the 1934 Exchange Act, ch. 404, $\$ 14(a), 48$ Stat. 895 (1934), as amended 15 U.S.C. \& 78n(a) (1964) (proxy solicitation).

47. 377 U.S. at 433.

48. Id. at 432 .

49. The justification for implying the action in Borak was that the private action provided a "necessary supplement" to agency enforcement. Id. This is, of course, the implicit assumption of Perma Life, and this must also be the basis of the private securities actions. 
investor situation, Perma Life automatically applies because the standards for application of Perma Life and Borak are identical. ${ }^{50}$

\section{Subtle Differences in Applying Perma Life's Method of Achiev- ing Enforcement}

Serzysko displayed obedience to the thrust of Perma Life-that recovery is to be considered in terms of enforcement-and the result on the facts seems correct. However, the Serzysko approach implicitly fails to give full effect to Perma Life's method of achieving enforcement by focusing on whether permitting recovery would encourage plaintiffs to violate the statute and not on whether it would discourage defendant violations. Such an approach fails to make use of an important difference between the antitrust and margim regulations, ${ }^{51}$ namely, that in the latter case the entire duty of compliance is on one party - the broker-defendant.

In Serzysko ${ }^{52}$ a sophisticated, experienced investor who had deceived the lender by falsifying a purpose statement ${ }^{53}$ sought to recover

50. However, while both Perma Life and Borak are grounded in the threat theory, they relate to different issues. Borak involved only the abstract question of whether a private action should be implied; there was no issue before the Court concerning the conduct of the plaintiff. The plaintiff in Borak was not involved in the defendant's violation, and Borak's analogy to antitrust was simply based on the rccognized role that the threat of treble damages by an injured party could play in deterring violations. The specific relation between conduct and enforcement remained unarticulated until Perma Life. Therefore, the significance in juxtaposing Perma Life and Borak is that Perma Life's specific treatment of the relation of conduct to enforcement gives substance to the Borak perspective of effectuating policy. In determining the extent to which private action should be made absolute, the margin cases must look to Perma Life. Thus, the argument that Borak's rationale means that conduct is no longer relevant is without merit. But see Comment, Civil Liability Under Regulation T: An un-Friendly Approach to the Pearlstein Case, 56 Iowa L. REv. 446 (1970).

51. The significant difference between antitrust and margin regulation is that, in the latter, the entire duty of compliance is on one party-the broker.

52. Serzysko involved a violation of Federal Reserve Board Regulation U while Pearlstein [see text accompanying notes 73-79 infra] involved a violation of Regulation T. Section 7(a) of the 1934 Exchange Act, ch. 404, § 7(a), 48 Stat. 886 (1934), as amended 15 U.S.C. $\$ 78 \mathrm{~g}$ (1964), delegated to the Federal Reserve Board the authority to promulgate rules to regulate the "amount of credit that may be initially extended and subsequently maintained on any security . . . registered on a national securities exchange." Pursuant to this authority, Regulation T [12 C.F.R. $\S 220$ (1970)] and Regulation U [12 C.F.R. \$ 221 (1970)] were adopted. Regulation $T$ governs the extension of credit to a customer by any member of a national exchange or by a broker or dealer transacting business with a member, while Regulation $U$ covers loans by banks for the purpose of purchasing or carrying securities. Both prescribe minimum margin requirements of 70 percent of the current markct value of the securities. Regulation $T$ further requires that the necessary margin deposit be inade within four days [12 C.F.R. $\$ 220.3(\mathrm{e})(1970)]$ or within seven days if the customer has a "special cash account" [12 C.F.R. $\$ 220.4$ (c) (1970)].

53. Lending institutions require that a statement of purpose be filed in order to meet the requirements of 12 C.F.R. $\$ 221.1$ (a) (1970), which reads in relevant part: 
losses resulting from the liquidation of securities at a depressed value on the theory that the lender had failed in its duty to use reasonable diligence in determining the true purpose of the loan. The plaintiff, when asked to make a purpose statement, intentionally misrepresented to the lender that he was not going to use the loan to carry ${ }^{54}$ securities. When the market declined and plaintiff was unable to furnish additional collateral, the bank sold the securities and applied the proceeds to the debt, leaving a balance of approximately $\$ 12,000 . .^{55}$ After liquidation the value of the stock sold rose 250 percent, and plaintiff sued for this loss in appreciation. ${ }^{56}$ The lender counterclaimed for the amount remaining on the loan. In denying relief to either party, the court punished the lender for his negligence and the plaintiff for his deceptive methods.

To support its conclusion that the plaintiff should be denied recovery, Serzysko distinguished Perma Life on two grounds. The first basis for distinction was statutory: antitrust provides an express treble damage action surpassing the public interest in the margin action, and the plaimtiff in antitrust, if involved in the wrongdoing, is subject to civil and criminal penalties. ${ }^{57}$ The second basis was factual: the defendant, unlike his counterpart in Perma Life, was inactive and unaware of the violation. ${ }^{58}$ Although Serzysko did not elaborate, this factual difference may mean that there is less deterrent effect in allowing a private action in margin cases since it is niore difficult to deter an unknowing defendant. ${ }^{59}$ However, it is difficult to see the relevance of the additional penalties; the private action is intended to deter the defendant, and the existence of additional penalties agamst the plaintiff would not inake this action any more effective. ${ }^{60}$ And, as

[N]o bank shall extend any credit secured directly or indirectly by any stock for the purpose of purchasing or carrying any margin stock in an amount exceeding the maximum loan value of the collateral, as prescribed from time to time for stocks . . . .

54. 12 C.F.R. 221.3(b) (1970) defines "carrying" as encompassing a loan made for the purpose of reducing or returning indebtedness incurred to purchase that stock. Such "carrying" is prohibited by 12 C.F.R. $\$ 221.1$ (a) (1970).

55. 290 F. Supp. at 76.

56. Id. at 82 .

57. Id. at 88 .

58. Id.

59. The situation where the defendant did not know of the violation is clearly different from Perma Life. See text accompanying notes 65-69 infra for the significance of this difference.

60. Although Perma Life did note, in passing, that recovery would not encourage violations by others in the plaintiff's position due to potential hability to third parties [392 U.S. at 139], this was not determinative. If it were, recovery in an equal fault situation should automatically result because others in the same position as plaintiff would be equally discouraged from suing. Rather, the determinative factor in Perma Life was the policing effect of the threat. The focus in Perma Life was the effect on the defendant, a fact Serzysko's approach overlooked. 
noted earlier, the attempt to distinguish antitrust decisions on the basis of disparate public interest is invalid. ${ }^{B 1}$

As to the issue of plaintiff's conduct in a private action pursuant to a regulatory statute, Serzysko considered Borak and Perma Life together to mean that recovery depended solely upon whether such recovery promoted enforcement of the regulations. ${ }^{62}$ Enforcement, Serzysko concluded, is achieved by developing rules in private actions involving a culpable plaintiff and defendant that "tend to encourage the observance of the statute and to deter nonobservance of it." ${ }^{33}$ Recovery was denied the plaintiff because otherwise an investor would be encouraged to use deceptive ineans to secure illegal loans-he could either keep the profits or, if the speculation proved unprofitable, recover dainages from the lender. The lender's counterclaim was denied to inspire more diligent conduct on his part. ${ }^{84}$

While this result looks correct on its facts, determining whether recovery will encourage plaintiff's compliance with the regulation represents a divergence from Perma Life's emphasis on the threat. The focus in Perma Life was on the defendant-whether the threat would effectively deter him from violations, not whether denial would encourage plaintiff's observance. There is no suggestion in Serzysko that its approach is to be restricted to situations where the defendant is unaware; in fact Serzysko cited the then-recent Moscarelli v. Stamm ${ }^{65}$ decision as authority for focusing on the issue of plaintiff's observance. The salient aspect of this citation to Moscarelli is that Moscarelli also afforded two possible rationales: plaintiff participation and defendant unawareness. In Moscarelli, decided prior to Perma Life, the plaintiff investor conspired with the defendant's employees to extend unlawful credit to the plaimtiff, a plan of which the defendant was unaware. ${ }^{68}$ Thus, Serzysko presented an opportunity to restrict Moscarelli to cases where the defendant is unaware. But instead, Serzysko cited Moscarelli as a situation in which a willful participant in the violation was denied recovery in order to secure observance of the statute. ${ }^{67}$ This focus on the plaintiff's observance apparently extends to a situation where the defendant is aware and knowledgeable. ${ }^{.8}$

61. See note 6 supra.

62. $290 \mathrm{~F}$. Supp. at 89.

63. Id.

64. Id. at 90 .

65. 288 F. Supp. 453 (E.D.N.Y. 1968). The court held that recovery should be denied a plaintiff willfully participating in the violation in order to discourage his attempt to speculate excessively. Id. at 457.

66. Id. at 455 .

67. 290 F. Supp. at 90.

68. See Aubin v. Hentz, 303 F. Supp. 1119 (S.D. Fla. 1969), which cited Serzysko and Moscarelli for the proposition that plaintiff's willful participation in a violation may preclude recovery. 
Failure to give full effect to the threat aspect of Perma Life leads to two important differences in result from a proper application of Perma Life: First, granting recovery may often encourage non-observance by the plaintiff and simultaneously deter the defendant. In such a situation, to focus on the conduct of the plaintiff may ignore the possibility that the deterrence of the defendant created by allowing recovery outweighs the encouragement of other potential plaintiffs to violate the statute. Second, the emphasis on encouraging the plaintiff's observance could cause the court to ignore important statutory provisions that militate in favor of recovery even in the absence of sanctions that encourage plaintiff's observance. For instance, in Serzysko the defendant had the sole responsibility for compliance with the margin requirements-a constant factor making for certainty and predictability that led Pearlstein to view the absence of plaintiff's bability as a means of achieving enforcement, not as an inhibition. ${ }^{69}$

Although the defendant's lack of knowledge in both Serzysko and Moscarelli may negate the existence of a threat, the issue of recovery should still consider the deterrent effect on the defendant. In fact, when the duty of compliance is solely on the defendant, as in inargin violations, the analysis should focus solely on the defendant. ${ }^{70}$ To focus on the plaintiff's conduct is appropriate, if at all, only in cases of an unknowing defendant.

Pedrlstein represents a strict obedience to the entire Perma Life mandate. After finding Perma Life to be pertinent, ${ }^{71}$ Pearlstein focused on the effect of recovery on the defendant. Although, as Pearistein readily recognized, contributory fault had been adopted where the defendant was unknowing, Pearlstein intimated that its approach might well undermine Serzysko and Moscarelli, even though the defendant in Pearlstein was completely aware of the violation. ${ }^{72}$

In Pearlstein, a broker extended credit beyond the seven-day compulsory liquidation date ${ }^{73}$ in two separate transactions. The experi-

69. See text accompanying notes 76-80 infra.

70. See text accompanying notes 76-82 infra.

71. 429 F.2d at 1141. For discussion of Pearlstein, see Comment, Civil Liability Under Regulation T: An un-Friendly Approach to the Pearlstein Case, 56 IowA L. Rev. 446 (1970); Note, Securities, 49 Texss L. Rev. 192 (1970).

72. $429 \mathrm{~F} .2 \mathrm{~d}$ at 1142 .

73. Regulation T, 12 C.F.R. $\S 220.4$ (c)(2) (1970), promulgated pursuant to 15 U.S.C. $\S 78 \mathrm{~g}(\mathrm{a})(1970)$, reads in part:

In case a customer purchases a security (other than an exempted security) in the special cash account and does not make full cash payment for the security within 7 days after the date on which the security is so purchased, the creditor shall, except as provided in sub-paragraphs (3)-(7) of this paragraph, promptly cancel or otherwise liquidate the transaction or the unsettled portion thereof. 
enced purchaser ${ }^{74}$ did not insist that the broker comply-in fact, he encouraged continuing the violation by asking for additional time when the broker eventually asked for the payments. After a period of time the securities were hiquidated, giving rise to a substantial loss beyond what would have occurred had the broker liquidated the stocks in conformity with the rules. The purchaser sued for the difference between the value of the shares after seven days and their value upon liquidation..$^{75}$ The court allowed recovery on a theory that would apply in any case where both the purchaser and broker were knowledgeable.

After noting that the implied action constitutes an integral enforcement mechanisin ${ }^{76}$ and disposing of the issue of plaintiff's conduct, ${ }^{77}$ Pearlstein observed that Perma Life itself is not direct authority for granting absolute recovery where no coercion exists and the investor benefits equally with the defendant in the violation. In order to make recovery absolute in a situation where the plaintiff is not coerced but encourages the violation, Perma Life inust be distinguished as a situation where both parties had a duty not to engage in the proscribed action; in the margin situation, only the broker has the duty of compliance. $^{78}$ Pearlstein considered the broker's duty of coinpliance dispositive and made recovery absolute. ${ }^{79}$ The court reasoned that since even knowledgeable, experienced investors are not immune froin unwise and greedy speculation, ${ }^{80}$ strict observance of the margin rules can only be achieved through the broker. Therefore, the broker's civil liabihty becoines a tool for achieving compliance with the rules.

Furthernore, distinguishing Perma Life's possible denial of recovery in Pearlstein's particular equal benefit situation is nevertheless

74. The purchaser was a retired lawyer who had spent over a decade actively "playing" the market. He had arranged similar loans in the past. 429 F.2d at 1145 .

75. Id. at 1139 .

76. Aware of the necessity that the private action be integral to the enforcement of the scheme, the majority noted that private actions are a "highly effcctive means of protecting the economy as a whole from margin violations by brokers and dealers." Id. at 1140.

77. Reflecting the Perma Life line of reasoning, the court declared:

$[T]$ he danger of permitting a windfall to an unscrupulous investor is outweighed by the salutary policing effect which the threat of private suits for compensatory damages can have upon brokers and dealers above and beyond the threats of governmental action by the Securities and Exchange Commission.

Id. at 1141 .

78. "Unlike the antitrust laws which forbid both seller and buyer to enter into a proscribed trausaction, the federally imposed margin requirements forbid a broker to extend undue credit but do not forbid customers from accepting such credit." Id.

79. Id.

80. "[T]he original need for margin requirements undoubtedly derived from the common desire of investors to speculate unwisely on credit." $I d$. 
within Perma Life's mandate since Perma Life authorizes absolute recovery when it promotes enforcement of a regulatory statute. ${ }^{81}$ The different result in margin regulation derives from the imvestor's immunity from potential liability, a factor that actually enhances enforcement. In antitrust, the internal relation between the two co-conspirators is such that, if recovery were allowed, their mutual ability to sue, should damage result from their illegal agreement, may actually encourage participation in an illegal conibination. Both the occurrence and the location of damage is uncertain. Thus, antitrust co-conspirators are simultaneously deterred by the threat of suit and encouraged by its possibility. ${ }^{82}$ On the other hand, in margin cases, or under any statute where the duty of compliance is placed solely on one party, the absence of civil liability for the plaintiff means that allowing recovery will enhance enforcement. For example, the plaintiff in Pearlstein admitted his liability for the original contract price but wanted to limit his loss to that incurred within the seven-day period. ${ }^{83}$ While allowing the plaintiff to recover encourages him to perpetuate the broker's violation, it is the broker who remains in ultimate control of the violation in the first instance. The broker-defendant has no incentive to continue the violation as does the defendant in illegal antitrust cases. ${ }^{84}$

Pearlstein considered both Serzysko and Moscarelli as cases where the defendant was unaware of the violation for which he was being sued, and the majority expressly refused to attack either case. ${ }^{85}$ However, the Serzysko and Moscarelli approach can serve to undermine the Pearlstein position. The dissent ${ }^{86}$ cited Serzysko and Moscarelli as authority for denying recovery to a plaintiff on the basis of his contributory fault. ${ }^{87}$ Focusing on the plaintiff's conduct, as the dissent adımits, necessarily means that enforcement must be sacrificed to some degree $\mathrm{m}$ order to prevent recovery to an undeserving plaintiff. ${ }^{88}$ But,

81. See text accompanying notes 31-33 supra.

82. See text accompanying notes 36-37 supra.

83. 429 F.2d at 1139.

84. A broker who continues to violate the regulations may admittedly gain a favorable repntation among investors who seek such brokers; however, allowing investors to recover for excess losses should render such brokers a scarcity. This assumption is crucial; if it is untrue, the whole basis for the private action fails because it would mean that the action is not effective as an enforcement tool.

85. Although two of them [Serzysko and Moscarelli] do mdicate that certain kinds of contributory fault may bar suit against a broker in this context, the kinds of contributory fault there involved go beyond knowledge of the margin requirements to concealment or misstatement of material facts. Consequently we decline to follow or to attack these holdings.

429 F.2d at $1141-42$.

86. Id. at $1145-49$ (Friendly, J.).

87. Id. at 1148-49.

88. Judge Friendly's opinion was not solely grounded in a concern for the equities. He recognized Perma Life's significance for securities, although he found it not 
according to Perma Life, the underlying goal is enforcement, and the general principles enunciated by the Pearlstein majority better achieve this goal since they maximize the possibilities of the private action threat. ${ }^{80}$

\section{B. Perma Life's Application to Private 10b-5 Actions}

The two cases that have considered Perma Life's pertinence to 10b-5 actions ${ }^{90}$-Kuehnert v. Texstar Corp. ${ }^{91}$ and Nathanson v. Weis,

pertinent to the case at bar. His rejection was based on a coinbination of enforccment policy and a concern that shifting the risk of market decline from the investor to the broker when the plaintiff is an experienced investor who encourages the SEC is unable to police a multitude of violations, if for no other reason than lack of manpower. Certainly there has been inadequate regulation of the market to date. See Recent Decisions, 5 GA. L. Rev. 166, 179 (1970) (a note on Pearlstein).

Finally, the dissent also argues that the majority approach encourages purchaser violations, thereby offsetting any deterrent effect. Id. at 1148 . However, there was no attempt to prove this claim, and it seems unlikely that purchasers could induce many violatious if the brokers are liable for any resulting loss.

Although Judge Friendly only alluded to the resulting inequity in allowing recovery [id. at 1149], it seems that his concern for individual equities played a substantial role in his opinion. A plea for allowing "isolated violations" is, in effeet, an admission that the majority approach does indeed create effective deterrence. Therefore, although Judge Friendly avoided refuting Perma Life and framed his dissent in terms of statutory policy, the real operative factor may well have been his desire to punish an unconscionable plaintiff. This position resembles that of the four Justices in Perma Life who believed that enforcement considerations should not predominate to the exclusion of all concern for individual equities. At the very least, Judge Friendly's opinion indicates that an application of Perma Life's mandate for enforcement will confront some resistance.

89. Support for the majority position in Pearlstein is found in the very recent decision, Avery v. Merrill Lynch, Pierce, Fenner \& Smith, 328 F. Supp. 677 (D.D.C. 1971), where the court granted an experienced invcstor's motion for sunumary judgment on the allegation that the defendant broker violated Regulation $T$. While expressing disdain for the conduct of the plaintiff investor, Avery adopted Pearlstein's reasoning and decided that the primary purposes of the margin rules would best be served by denying the in pari delicto defense.

The import of Avery to this discussion is minor beyond the support given to Pearlstein. The facts are analogous and present no new diniensions. The influence of Perma Life is made obvious by specific reference [Id. at 680], and the "threat" theory is adopted as the mechanism for effectuating statutory policy. Furthermore, Avery views the denial of in pari delicto as preserving congressional intent to place the onus of compliance on the broker and rejects the suggestion in Serzysko, Moscarelli, and Judge Friendly's dissent in Pearlstein that the broker be given a defense in some cases because Congress did not intend solely to protect the investor. Id. at 679-80. Avery concludes that these suggestions becoine operative only in situations of deceit or fraud.

90. 17 C.F.R. $₹ 240.10$ b-5 (1970) reads:

It shall be unlawful for any person, directly or indirectly, by the use of any means or instrumentality of interstate commerce, or of the mails or of any facility of any national securities exchange, (a) To employ any device, scheme, or artifice to defraud, (b) To make any untrue statement of a niaterial fact or to omit to state a material fact necessary in order to make the statements made, in the light of the circumstances uuder which they 
Voison, Cannon, Inc. ${ }^{22}$ - have reached apparently divergent conclusions. While the recent Nathanson case enthusiastically and fully adopted the Perma Life mandate, the 2-year-old Kuehnert decision, although accompanied by a strong dissent presaging the Nathanson position, rejected Perma Life as inapplicable to $10 \mathrm{~b}-5$ actions. However, the Kuehnert rejection was inore apparent than real; the inajority's approach is identical to one that properly invokes Perma Life, and the different results on the recovery issue can be explained by reasoning external to the Perma Life issue. Consequently, there is no barrier to applying Perma Life to 10b-5 actions; on the contrary, the judiciary has set forth strong authority for doing so.

In Kuehnert, the majority and dissent sharply divided as to Perma Life's pertinence. Kuehnert involved the unique situation of a tippee suing a tipster under Rule 10b-5, alleging that the tipster had disclosed false information upon which the tippee detrimentally relied. The Fifth Circuit held that plaintiff Kuehnert, a tippee and under the same obligations of rule $10 \mathrm{~b}-5$ to disclose material information as is the corporate insider, had violated his duty to refrain from trading or, alternately, to disclose his information; ${ }^{93}$ he therefore was barred by lis own illegal conduct from seeking recovery from the tipster. In reaching the conclusion that in pari delicto ${ }^{94}$ can bar recovery in this and

were made, not misleading or (c) To engage in an act, practice, or course of business which operates or would operate as a fraud or deceit upon any person, in connection with the purchase or sale of any security.

The Rule was promulgated pursuant to Section 10(b) of the Securities and Exchange Act, which provides:

It shall be unlawful for any person, directly or indirectly, by the use of any means or instrumentality of interstate commerce or of the mails, or of any facility of any national securities exchange .... (b) To use or einploy, in connection with the purchase or sale of any security registered on a national securities exchange or any security not so registered, any manipulative or deceptive device or contrivance in contravention of such rules and regulations as the Commission may prescribe as necessary or appropriate in the public interest or for the protection of investors.

15 U.S.C. \& 78j(b) (1970).

91. 412 F.2d 700 (5th Cir. 1969). For helpful analysis of Kuehnert, see Nea, Limitations on Defenses Under 10(b): In Pari Delicto and Unclean Hands, 5 U. RicHMOND L. Rev. 251 (1971); Comment, Tipsters, Tippees and the Doctrine of In Pari Delicto, 50 B.U.L. Rev. 87 (1970); Comment, Securities Regulation: Doctrines of In Pari Delicto and Unclean Hands Held to Bar 10b-5 Recovery by Tippee Against Corporate Insider, 1969 DUKE L.J. 832.

92. 325 F. Supp. 50 (S.D.N.Y. 1971).

93. Consequently, both parties were in violation of $10 \mathrm{~b}-5$. The purpose of the statute is to equalize the bargaining position of investors by requiring the insider to disclose or refrain from trading. See Speed v. Transamerica Corp., 99 F. Supp. 808, 829 (D. Del. 1951). To promote this pohicy of equalization, lower echelon employees and tippees are within the scope of 10b-5. SEC v. Texas Gulf Sulphur Co., 401 F.2d 833, 848 (2d Cir. 1968), cert. denied, 394 U.S. 976 (1969); Ross v. Licht, 263 F. Supp. 395, 410 (S.D.N.Y. 1967). Kuehnert involved both kinds of violations, and let the loss lie where it fell.

94. The parties were not technically in pari delicto since their violation did not 
other 10b-5 actions, ${ }^{95}$ the majority distinguished Perma Life as limited to the antitrust area and inapplicable to private securities actions. ${ }^{00}$

In distinguishing Perma Life, the majority flatly asserted that plaintiff's conduct alone may provide the basis for denying relief. ${ }^{.7}$ However, the majority did not decide the issue of recovery on the basis of plaimtiff's moral worth; instead, they adopted an approach that conditioned the application of in pari delicto on whether its invocation would effectuate the policies underlying 10b-5-to increase the "protection afforded the investing public." 08 Thus, plaintiff Kuehnert's private action was demied because the majority felt that enforcement of $10 \mathrm{~b}-5$ policies would be better served by denying his claim.

In contrast, the dissent would have allowed recovery $m$ this situation and would have held Perma Life applicable to all 10b-5 actions.

merge into one, but this Comment assumes with the court that in pari delicto could be applied.

95. Both the majority and dissent were aware that this was the first case in which Perma Life had been cited by a culpable plaintiff and, consequently, that important precedent was being established.

96. The majority ruled Perma Life inapplicable because private actions regarding SEC violations do not involve the degree of public interest present in antitrust suits. However, this distinction is unsatisfactory because treble damages were created partially in response to factors not present here-the real possibility of retribution. See note 6 supra.

For additional support, the majority pointed out that the equitable defense of unclean hands is used in the proxy area. However, the case law here is uncertain. Although Guadiosi v. Mellon, 269 F.2d 873 (3d Cir.), cert. denied, 361 U.S. 902 (1959), allowed the defense, Union Pac. R.R. v. Chicago \& N.R.R., 226 F. Supp. 400 (N.D. Ill. 1964), emphasized that in the proxy area, there is an overriding public interest in protecting innocent shareholders. Allowing a person who committed an independent wrong to thwart a private action ignores this public interest, especially since the other shareholders may be unaware of the defendant's violations. More important, Borak and Perma Life seriously undermined the viability of this defense in the proxy area. The unclean hands defense is inconsistent with Borak's ruling that a private remedy is implied under the proxy solicitation rules in order to effectuate the congressional purpose of promoting "the free exercise of the voting rights of stockholders" by ensuring "complete" and "full" proxy solicitation. J.I. Case Co. v. Borak, 377 U.S. 426, 432 (1964).

As final support for the proposition that Perma Life was inapplicable, the majority noted that Perma Life itself suggested that recovery might be denied in the case of true co-conspirators. However, this does not preclude the applicability of Perma Life; both Serzysko and Pearlstein recognized that Perma Life had enunciated a new standard for recovery.

97. "We have small doubt but that actual illegal conduct should bar recovery." 412 F.2d at 703.

98. Id. at 704. In effect, the majority found, as did the dissent, that the $10 \mathrm{~b}-5$ action constitutes a mechanism to enforce the underlying policy of achieving equal bargaining position. Comment, Tipsters, Tippees and the Doctrine of In Pari Delicto, 50 B.U.L. Rev. 87, 92 (1970); Comment, Securities Regulation: Doctrines of In Parl Delicto and Unclean Hands Held to Bar IOb-5 Recovery by Tippee Against Corporate Insider, 1969 DURE L.J. 832, 836. This by itself warrants the application of Perma Life's mandate to set aside concern for punishing an unworthy plaintiff and, instead, to consider the actions solely in terms of enforcement. 
It argued that an implied $10 \mathrm{~b}-5$ action, like the express private antitrust action, vindicates an important public interest by contributing to the enforcement of the regulatory scheme. ${ }^{99}$ The dissent concluded that the "threat" method, under the facts of the case, slould be relied upon as the means of achieving enforcement. ${ }^{100}$ The real disagreement, then, between the majority and the dissent was not whether Perma Life was pertinent to $10 \mathrm{~b}-5$ actions but whether the "threat" theory should be adopted in that particular case.

Apparently, the majority failed to apply Perma Life because it felt that recognizing Perma Life's pertinence would inean that absolute recovery would always ensue, since conduct would no longer be relevant. Such a result was unacceptable because the court thought that recovery, on the Kuehnert facts, would not achieve deterrence as effectively as would denial. While recovery would deter the insider from disclosing false information to an investor, the tippee would get free and unhampered use of all information emanating from insiders, secure in the knowledge that damages could be recovered if the information proved false. Thus, the threat could only eliminate false information while the illegal but true information would still continue to flow and be used. ${ }^{101}$ The issue became whether deterring the tipster or the tippee would more effectively decrease the total quantity of inside information being used in the inarket. Considering each party to pose equal dangers to enforcement, and given the deterrent pressure already felt by the insider, ${ }^{102}$ the court denied recovery.

But, as the approach taken by the dissent reveals, the adoption of Perma Life does not necessarily require absolute recovery. Although the dissent did conclude that recovery should be made absolute in this case, it would use discretion in determining whether Perma Life's method would pernit recovery in other $10 \mathrm{~b}-5$ actions. The dissent justified its absolute approacli on the Kuehnert facts by arguing that recovery would create an effective deterrent agamst the disseminator of information and that action against the source most effectively curbed the use of inside information. ${ }^{103}$

99. "The massive increase in filing of $10 \mathrm{~b}-5$ cases . . . indicate[s] that the private suit will be a major weapon-and may be the inost important weapon-in attainment of the policies exemplified by the Act and the Rule." 412 F.2d at 706 .

100. Id.

101. Id. at 705 .

102. The pressures were those created by SEC v. Texas Gulf Sulphur Co., 401 F.2d 833 (2d Cir. 1968), cert. denied, 394 U.S. 976 (1969). 412 F.2d at 705. The reference to Texas Gulf Sulphur and the "equal dangers" posed by the parties were factors in the majority's statutory effectuation test.

103. "The best way to stop the misuse of confidential information is to discourage the insider-tipster from making the initial disclosure which is the first step in the chain of dissemination." 412 F.2d at 706. The dissent also argued that the rule could be extended to tippees who are no more than unsophisticated investors advised of a good 
In sum, Perma Life does not foreclose either the dissent's or the majority's result. Adopting the Perma Life mandate would not jeopardize the majority's analysis of how to curtail the use of inside information. The "threat" theory need not be fully adopted and extended when it is counterproductive. Perma Life's analysis prefers absolute private actions but only when they maximize enforcement. ${ }^{104}$

The Kuehnert majority position that Perma Life is not pertinent to $10 \mathrm{~b}-5$ private actions was rejected in the recent Nathanson decision. The plaintiffs, husband and wife, received inside infornation from the defendant brokerage firm that the stock of two companies ${ }^{105}$ would be exchanged on a one-for-one basis in a pending inerger. The tippee plaintiffs purchased the lesser valued stock, and, after the merger was consummated at a disadvantageous rate of exchange, the plaintiffs sued defendant brokers for the damages sustained. ${ }^{100}$ The defendants argued that the plamtiffs' voluntary participation precluded recovery. Although disgusted with the conduct of the experienced and knowledgeable tippees, ${ }^{107}$ Judge Weinfeld dismissed the defend-

deal by the broker. Ironically, nearly this situation arose in Wohl v. Blair \& Co., 50 F.R.D. 89 (S.D.N.Y. 1970). The Wohl court acknowledged that the availability of equitable defenses in private suits was not free from doubt but deferred to Kuehmert. 50 F.R.D. at 93. See note 8 supra. Decided two months prior to Pearlstein, the only relevant opinions available to the Wohl court were Kuelnert and Serzysko.

104. The dissent was prepared to set forth an enforcement doctrine of its own, in the event Perma Life could be construed to permit in pari delicto in an equal fault situation. Judge Godbold beheved that absolute recovery in all $10 \mathrm{~b}-5$ actions was necessary to make $10 \mathrm{~b}-5$ actions effective, producing the salutary effect of ensuring consistent case law and the exposure of litigants' unlawful conduct to third parties. 412 F.2d at 706 n.3. Thus, Judge Godbold was prepared to go beyond Perma Life if necessary.

However, Perma Life did not intimate that in pari delicto could be applied to equal fault; it only indicated that enforcement factors must be considered. See text accompanying notes 31-33 supra. To the extent that these additional factors aid enforceinent, they justify recovery in an "equal threat" situation, that is, when the deterrent situation is a toss-up.

Judge Godbold was trying to avoid judicial discretion. By creating a firm rule, the inherent problems of judicial discretion are obviated. Retaining discretion where the plaintiff is to some degree culpable affords the opportunity to interject a court's notion of equity against a culpable plaintiff in a supposed enforcement test, with the effect of compromising the asserted emphasis on policy. The real difficulty here is that there is no way to determine what the actual motive of a particular court is. For example, the Kuehnert majority reached the conclusion that the plaintiff's private action was "unnecessary" as a deterrent to the tipster because the effect of Texas Gulf Sulphur had already placed pressure upon the corporate insider. See note 102 supra. Therefore, it chose to deny recovery in order to subject both to deterrent pressure. However, Texas Gulf Sulphur had already placed pressure on the tippee, too. Such reasoning raises the real possibility that equitable considerations were involved.

105. The defendant's president was chairman of the board of each company. $325 \mathrm{~F}$. Supp. at 51.

106. Id.

107. Judge Weinfeld remarked, "The defendant understandably brands plaintiffs' claim 'absurd on its face'. ..." Id. at 52 . 
ant's motion for summary judgment, relying heavily on Perma Life to rule that in pari delicto is not available to a tipster. ${ }^{108}$

Judge Weinfeld framed the question in enforcement terms: ${ }^{109}$

The basic question . . . centers not about the claims asserted by plaintiffs against the defendant or the defense advanced in resistance to those claims, but rather about third parties not involved in the litigation-the investing public and what policy with respect to the allowance or disallowance of the defense would best serve to carry out the prime purpose of the securities laws to protect the investing public. ${ }^{110}$

In considering what policy best protects the public, Judge Weinfeld placed great weight on Perma Life's "strong suggestion of the unavailability of the defense of in pari delicto in securities violations . . . ."111 $\mathrm{He}$ recognized that Perma Life by itself could not be dispositive due to two important differences: first, in antitrust law Congress' purpose to secure auxiliary enforcement by private treble damage actions was clearly inanifested; and second, the plaintiff in Perma Life had been coerced into joining the illicit agreenent, whereas the Nathansons voluntarily acted upon the inside information in purchasing shares on a national stock exchange. However, despite these distinctions, Judge Weinfeld found the threat of private action basic to enforcing the purpose of each regulatory scheme, ${ }^{112}$ citing Pearlstein:

The court [in Pearlstein] . . . noted: "In our view the danger of permitting a windfall to an unscrupulous investor is outweighed by the salutary policy effect which the threat of private action suits for compensatory dainages can have upon brokers and dealers above and beyond the threats of governmental action by the Securities and Exchange Commission."113

The broker-dealer, and the issuer of securities, are at the fountainhead of the confidential information whereas the tippee is one step

108. Id. at 56.

109. Judge Weinfeld recognized that Kuehnert resembled his approach in that the controlling factor was protection of the investing public. Id. at 52 .

110. Id. at $52-53$.

111. Id. at 56.

112. Judge Weinfeld noted that a comparison of Perma Life with Borak revealed that "the policies underlying the private enforcement of the antitrust laws and the securities acts are quite similar," and that the threat played an equally important role in each regulatory scheme. Id. at 56.

113. Id. at 57, quoting Pearlstein v. Scudder \& German, 429 F.2d 1136, 1141 (2d Cir. 1970), cert. denied, 401 U.S. 1013 (1971). Judge Weinfeld took note of Judge Friendly's "heads I wim, tails you lose" argument in his Pearlstein dissent, which went to the investor's built-in indemnity against loss if in pari delicto is not invoked. He found this argument to have surface appeal but thought that the better focus was on the overall purpose of the securities acts rather than the windfall inuring to the investor. 
removed. ${ }^{114}$ While each is in a position to take advantage of the investing public, Judge Weinfeld concluded that the greater threat to the public is posed by the original insider. Adopting the reasoning of Judge Godbold's dissent in Kuehnert, Judge Weinfeld concluded that the most effective means of preventing the use of material inside information is to discourage the tipster from "making the initial disclosure which is the first step in the chain of dissemination." way to do this is to make the defense of in pari delicto unavailable to the defendant.

\section{Summary}

The four cases that have considered Perma Life attest to its pertinence to securities regulation. ${ }^{116}$ Therefore, whenever a securities regulation scheme rehes on private action for enforcement assistance, the real issue is whether Perma Life's method of achieving enforcennent should be adopted. Given Perma Life's express disclaimer regarding a noncoercive situation, the case is properly viewed as only a foundation from which to draw distinctions. The viability of the threat $\mathrm{m}$ each type of private securities action must be considered with respect to the statutory frainework within which the private action functions in order to ascertain Perma Life's proper application.

Pearlstein's application of Perma Life to the margin frannework and Nathanson's application of Perma Life to $10 \mathrm{~b}-5$ actions represent proper use of Perma Life in different statutory contexts. The private margin action was made absolute to stablize the national econoiny; the private $10 \mathrm{~b}-5$ action was made absolute to protect the imvesting public.

Since the primary purpose of securities laws is generally the protection of the investing public, the application of Perma Life to margin regulation holds less precedential value for future applications of Perma Life. Unlike $10 \mathrm{~b}-5$ actions, the margin case precedents are subject

114. Judge Weinfeld concluded that "brokers and issuers of securities are generally subjected to closer scrutiny under the Act than other persons, since they "have better opportunities to investigate and appraise the prospective earnings and business plans affecting securities' ..." Id. at 56, quoting Wilko v. Swan, 346 U.S. 427, 435 (1953).

115. Id. at 57, quoting Kuehnert v. Texstar Corp., 412 F.2d 700, 706 (5th Cir. 1969) (Godbold, J., dissenting).

116. The one decision refusing to recognize Perma Life's pertinence-Kuehnertrejects it only in rhetoric and is based on fundamental misconceptions of the Perma Life rationale. See text accompanying notes 100-04 supra. The other authority questioning Perma Life's pertinence-Judge Friendly's dissent in Pearlstein-although clearly implying that Perma Life is pertinent in some unspecified circumstances [429 F.2d at 1148], indicated by inference that the basic conflict surrounding the abolition of in pari delicto in Perma Life also presents a hurdle in securities law. See note 88 supra. However, taking the cases as a whole, Perma Life must be deemed pertinent to the securities area. 
to arguments restricting Perma Life's applicability to situations where the primary statutory purpose is not to protect the investor or where the duty of compliance rests solely on one party. Nevertheless, once Perma Life's pertinence is establislied, consideration of the threat in terms of specific statutory provisions is useful generally. For example, if a statute whose primary purpose is protection of the investing public places the burden of compliance on one party, Pearlstein's method for creating a viable threat is authoritative.

These distinctions can be illustrated by attempting to apply Perma Life to a private action under California securities law-a scheme devised primarily for the protection of the investing public.

\section{III}

\section{AN ARgument for Adopting Perma LIfE's MANDATE AND ITs "Threat" Method For ACHIEVING ENForCEMENT IN CALIFORNIA SECURITIES LAW}

The California Securities Law of $1968^{117}$ provides a purchaser of nonqualified ${ }^{118}$ corporate shares or stock in an issuer transaction ${ }^{119}$ an express rescission action against the issuer. ${ }^{120}$ But this express pri-

117. Ch. 88, $\S 2$, [1968] Cal. Stat. 243, codified at CAL. CoRP. Code $\$ 25000$ et seq. (West Supp. 1971).

118. "Nonqualified" corporate shares or stock are those not qualified by coordination [CAL. CORP. CODE $\$ 25111$ (West Supp. 1971) (evidence of registration under the Secnrities Act of 1933)]; notification [CAL. CoRP. CODE $\$ 25112$ (West Supp. 1971) (evidence of registration under the Securities and Exchange Act of 1934 or the Investment Act of 1940)]; or regular state qualification [CAL. CORP. CODE $\$ 25113$ (West Supp. 1971) (obtaining a permit from the Corporation Commissioner)]. The basic rule against the offer or sale of nonqualified shares is set forth in CAI. CoRP. CODE $\$ 25110$ (West Supp. 1971):

It is unlawful for any issuer to offer or sell in this state any security issued by it (other than in a transaction subject to Section 25120), whether or not by or through underwriters, unless such sale has been qualified under Section 25111,25112 or 25113 (and no order under Section 25140 or subdivision (a) of Section 25143 is in effect with respect to such qualification) or unless such security or transaction is exempted under Chapter 1 (commencing with Section 25100) of this part.

119. An issuer transaction is one that is directly or indirectly for the benefit of the issuer-where any part of the purchase price of the securities inures to the issuer. H. Marsh \& R. Volk, Practice Under the California Securtites Law of 1968 347-49 (1969); CaL. CoRp. CODE $\$ 25011$ (West Supp. 1971). An indirect benefit inures to the corporate entity, for example, when a director or controlling shareholder offers or sells his own shares with part of the inoney going to the corporation.

120. The retnedy available to the purchaser is set forth in CAL. CORP. CODE $\S 25503$ (West Supp. 1971), which reads in pertinent part:

Any person who violates Section $25510 \ldots$ shall be liable to any person acquiring from him the secnrity sold in violation of such section, who may sue to recover the consideration he paid for such security with interest thereon at the legal rate, less the amount of any incoine received therefrom, upon the tender of such security, or for damages (if he no longer owns the security) equal to the difference between (a) his purchase price plus interest 
vate action is not absolute. The defense of in pari delicto, although not statutorily provided, ${ }^{121}$ is available to a defendant-issuer when the purchaser has involved himself to an equal degree with the issuer ${ }^{122}$ in the issuance of unqualified securities. ${ }^{123}$ Although no decision in this area has yet referred to Perma Life, the policy considerations underlying Perma Life apply here just as they do to federal securities law. ${ }^{124}$

at the legal rate from the date of purchase and (b) the value of the security at the time it was disposed of by the plaintiff plus the amount of any incoine received therefrom by the plaintiff. . . .

Note that the statute does not distinguish whether the issuer had knowledge of the violation.

121. This defense is not expressly provided by statute in the 1968 changes, but neither did the former rules provide for it. Ch. $384 \&$ 1, [1949] Cal. Stat. 698. See, e.g., Western Oil Co. v. Venago Oil Corp., 218 Cal. 733, 24 P.2d 971 (1933); Eberhard v. Pacific Southwestern L\&M Corp., 215 Cal. 226, 19 P.2d 302 (1932). The courts have declared in pari delicto an appropriate consideration. Southern Cal. First Nat'l Bank v. Quincy Cass Associates, 3 Cal. 3d 667, 478 P.2d 37, 91 Cal. Rptr. 605 (1970). See H. Marsh \& R. VolK, supra note 119, at 483, which advises that in pari delicto would be appropriate under the new law. The prior case law will apply because section 25503 merely codified the previous judicial position.

For an analysis of previous decisions, see generally Dahlquist, Regulation and Civil Liability Under the California Corporate Securities Act: IV, 34 CALIF. L. REv. 697, 697-701 (1946); Note, Noncomplying Securities in California: Judicial Protection of Interests Under Corporations Code \$ 26100, 18 STAN. L. Rev. 1184, 1184-89 (1966).

122. At issue in an in pari delicto analysis is the relationship between the plaintiff and the issuer. The term "issuer" includes the active participants in the illegal issuance, and the plaintiff's conduct is ineasured against that of such participants. See Smith v. Turner, 238 Cal. App. 2d 141, 148-49, 47 Cal. Rptr. 582, 587 (2d Dist. 1965). This Comment argues that responsibility for compliance with the qualification requirements, and not participation in the violation, is the appropriate standard. This means that a plaintiff-purchaser's conduct is measured against the director's ultimate responsibility for compliance, irrespective of such concepts as active or inactive participation. See text accoinpanying notes 130-32 infra.

123. Underlying the use of in pari delicto here are the same considerations as in antitrust: to prevent an unconscionable plaintiff froin profiting from his own wrongdoing and to effectuate the qualification rnles by allowing all purchasers not equally at fault to recover. See Miller v. California Roofing Co., 55 Cal. App. 2d 136, 142, 130 P.2d 740, 744 (1st Dist. 1942).

124. The argument for applying Perma Life to section 25503 express actions [see note 120 supra] to its federal counterpart-section 12(1) actions under the Securities Act of 1933 [15 U.S.C. $\$ 77 l(1)$ (1970)]. Section 12(1) provides a right of rescission to a purchaser of securities sold to him in violation of the registration provisions of the 1933 Act, without regard to fault on part of the seller. This express action, aimed at creating a deterrent, is properly viewed as an enforcement mechanism. Shulman, Civil Liability and the Securities Act, 43 Yale L.J. 227 (1933); Douglas \& Bates, The Federal Securities Act of 1933, 43 YALE L.J. 171 (1933). However, in pari delicto has been deemed an appropriate consideration by the two leading section 12(1) cases, although neither case applied the defense to its own facts. Can-Am Petroleuin Co. v. Beck, 331 F.2d 371 (10th Cir. 1964); Katz v. Amos Treat \& Co., 411 F.2d 1046, 1054 (2d Cir. 1969). In fact, Can-Am adopted the reasoning of Miller v. California Roofing Co. [see note 127 infra], one of the leading California cases to invoke the in pari delicto defense. $331 \mathrm{~F} .2 \mathrm{~d}$ at 373 . For these reasons, the argument regarding the California application of Perma Life applies to section 12(1) 
The qualification requirements are intended to effectuate the main purpose of the entire California regulatory schene: prevention of fraud before it occurs. ${ }^{125}$ The requirement that a security be qualified before it can be offered or sold affords the Corporation Commissioner an opportunity to review the proposed issuance to ensure that it is fair. ${ }^{126}$ The California judiciary recognized early that denying a purchaser's private action on a minimal showing of fault would render the permit requirements ineffective. ${ }^{127}$ Courts recognized that the private action is integral to the enforcement of one of the regulatory scheme's basic provisions, and the judicial doctrine of in pari delicto has developed with the emphasis on the word "equal" rather than on "fault." Consequently, a finding of in pari delicto now requires a showing of truly equal fault. ${ }^{128}$

Nevertheless, recovery still ultimately depends on the degree of plaintiff's involveinent in the defendant's violation. ${ }^{129}$ This imcomplete

actions, too. See Comment, Applicability of Waiver, Estoppel, and Laches Defenses to Private Suits Under the Securities Act and SEC Rule 10b-5, 74 YALE L.J. 1477, 1482-83 (1964), which suggests, in Perma Life-like reasoning, that equitable defenses should be mapplicable to section $12(1)$ actions in order to effectuate compliance with the registration requirements.

125. See Jennings, The Role of the States in Corporate Regulation and Investor Protection, 23 LAw \& CONTEMP. Prob. 193, 213 (1958).

126. CAL. CORP. CODE $\S 25140$ (West Supp. 1971) requires that an issuance be fair, just, and equitable.

127. Miller v. California Roofing Co., 55 Cal. App. 2d 136, 143-44, 130 P.2d 740, 745 (1st Dist. 1942) stated:

Where contracts or transactions are prohibited by positive statute for the sake of protecting one set of men from another set of men-the one froin their station and condition being liable to be imposed upon by the other-in the furtherance of these statutes, the person injured, after the transaction is finished and completed, may bring action and defeat the contract. ... This is true even though both parties are to some extent involved in the illegality. In such event, since the policy of the law designed to discourage illegal agreements comes in conflict with that policy which demands the effective enforcement of the Corporate Securities Act, the law differentiates the guilt of the parties, because refusal of rehef to the less culpable would involve harmful effects wholly out of proportion to the requirements of individual punishment or the discouragement of illegal contracts. ... When the action is between the purchaser and the corporation, the law attaches such great importance to the policy underlying the Blue Sky Law that the purchaser must be equally culpable with the corporation before he will be lield to be in pari delicto. . . .

See Dahlquist, Regulation and Civil Liability Under the California Corporate Securities Act, 34 CALIF. L. REv. 695, 697-699 (1946).

128. Maner v. Mydland, 250 Cal. App. 2d 526, 58 Cal. Rptr. 740 (2d Dist. 1967); Smith v. Turner, 238 Cal. App. 2d 141, 47 Cal. Rptr. 582 (2d Dist. 1965). See Note, Noncomplying Securities in California: Judicial Protection of Interests Under Corporations Code $\$ 26100,18$ STAN. L. REv. 1184, 1188 (1966).

129. See text accompanying notes 138-42 infra. This constricted allegiance to the basic principle that a wrongdoer should not profit from his wrongdoing is similar to the concern expressed by the four Justices in Perma Life who advocated the retention of im pari delicto. See note 33 supra. 
deference to enforcement considerations, and the necessity of the purchaser's private action to the overall enforcement scheme in California, present conditions similar to those faced by the Perma Life court and argue strongly for application of the Perma Life philosophy, an argument that is reinforced by its application to implied private actions in federal securities law.

The private action for rescission in question here involves a purchaser suing an issuer, in which is vested the entire responsibility for qualification of the securities. ${ }^{130}$ Simce the issuer can be conceptual ized as either the corporation or the directors, ${ }^{131}$ the potential defendant can be singled out and isolated. In attempting to achieve enforcement by making recovery absolute, Pearlstein's focus on the defendant's duty ${ }^{\mathbf{1 3 2}}$ and Nathanson's emphasis on the constant defendant ${ }^{133}$ would require that recovery be made absolute for all purchasers except directors who participate in the issuance of illegal shares to themselves. By holding the issuer to his duty, directors will be motivated to fulfill their duty of compliance. Furthermore, compliance is facilitated by denying a director-plaintiff an action against the corporation for an illegal issuance that he controlled.

The argument for the adoption of this enforcement formula stands on its own. However, there is another reason: adoption of this formula would, in the process, resolve the conflict between the two different in pari delicto approaches that presently control the issue of rescission. ${ }^{134}$

\section{A. The Present In Pari Delicto Tests ${ }^{135}$}

\section{The Participation Test}

The dominant in pari delicto approach in California securities law is the participation test, which measures the relative culpability

130. See notes 118,120 supra. In practice, the ultimate responsibility for the issuance falls on the directors since a corporate issuance cannot proceed without director approval. The directors have ultimate control over the qualification process.

131. See note 122 supra.

132. See text accompanying notes 73-82 supra.

133. See text accompanying notes 108-15 supra.

134. Maner v. Mydland, 250 Cal. App. 2d 526, 58 Cal. Rptr. 740 (2d Dist. 1967) (in pari dehicto measured in terms of duty [see text accompanying notes 150.53 infra]); Smith v. Turner, 238 Cal. App. 2d 141, 47 Cal. Rptr. 582 (2d Dist. 1965) (in pari delicto measured in terms of participation [see text accompanying notes 138-42 infra]). The adoption of the proposed formula would achieve the same result as the duty test, although under a different rationale. See text accompanying notes 155-60 supra.

135. That some of the following cases do not involve the precise transaction upon which we are centering makes no difference for our purposes. They are relevant because they reflect, within the context of their factual setting, the dynamics of either the duty or the participation test. 
of each party in terms of his respective participation in the violation. This test places the purchaser in pari delicto when there is enough active participation in the issuer's violation to be in equal fault ${ }^{136}$ with the seller. ${ }^{137}$ But what degree of participation satisfies the equal fault requirement is not an easy question. Examination of the evolution of the requirennent, most fully explicated in Smith $v$. Turner, ${ }^{138}$ reveals inconsistencies and the absence of precise rules. There is only one clear equal fault situation: a director who authorizes the sale to himself of unqualified corporate securities. ${ }^{139}$ With regard to participating purchasers other than directors, the determination of in pari delicto is less certain. The elaborate reasoning employed in Smith itself indicates the difficulty in deciding just how much participation is necessary to be equally at fault.

In Smith, the investors, who were imexperienced in corporate affairs, entered into a presubscription agreement with the issuer that violated the qualification requirements. Later, when the issuer tried to obtain the shares, he mduced the purchasers to make misrepresentations to the Commissioner. ${ }^{140}$ At issue was whether the purchaser's participation in the fraudulent scheme devised by the issuer barred rescission by the purchaser. Smith considered the issue a close one and adopted an approach that carefully compared the conduct of the issuer and the purchaser to determine which was the greater wrongdoer, on the ground that an in pari delicto defense should not be allowed when the issuer is the greater wrongdoer because effective deterrence would not be attained. The court focused on the issuer's inducement of the plaintiff into the fraudulent agreement and allowed recovery. ${ }^{141}$ Neither the factor of corporate mexperience nor the possible coercive element in the purchaser's assent to the fraudulent agreement were considered determinative. ${ }^{142}$

136. A high degree of fault is required for equal fault by California courts. See text accompanying notes 127-28 supra.

137. Mere knowledge of the issuer's violation on the part of an acquiescing buyer is insufficient for a successful in pari delicto defense. Randall v. California Land Buyers Syndicate, 217 Cal. 594, 20 P.2d 331 (1933).

138. 238 Cal. App. 2d 141, 47 Cal. Rptr. 582 (2d Dist. 1965).

139. For example, in Hargiss v. Royal Air Properties, Inc., 206 Cal. App. 2d 406, 23 Cal. Rptr. 678 (4th Dist. 1962), a director refused to accept sliares he was to receive pursuant to an illegal plan that he had suggested and directed. The court found he instigated the plan of whlich he complained, thus making limself at least as blameworthy as the other directors. There is no disagreement regarding this situation: the director's action is barred. See Holmberg v. Marsden, 39 Cal. 2d 592, 248 P.2d 417 (1952); Weinstock v. L.A. Carpet, Inc., 234 Cal. App. 2d 809, 44 Cal. Rptr. 852 (2d Dist. 1965); Russek v. Tomark Jet Components, Inc., 152 Cal. App. 2d 131, 312 P.2d 737 (2d Dist. 1957).

140. 238 Cal. App. $2 d$ at 148, 47 Cal. Rptr. at 586.

141. Id. at $153,47 \mathrm{Cal}$. Rptr. at 590 .

142. Id. at 151-52, $47 \mathrm{Cal}$. Rptr. at 588 . 
Using its equal fault test to determine if the issuer is the greater wrongdoer, Smith criticized Miller v. California Roofing Co., an earlier case ${ }^{143}$ that involved similar facts but allowed the in pari delicto defense. ${ }^{144}$ In Miller, in contrast to Smith, the employee-purchaser knew from the outset that a permit was required and that it had not been obtained. After being turned down initially, he eventually convinced the defendant-employers to sell him the shares. Subsequently, at the issuer's request, he entered into an agreement to represent to the Commissioner that no sale had taken place. ${ }^{145}$ The Miller court considered that the purchaser's enthusiastic efforts to obtain the shares that he knew were not qualified justified a finding of in pari delieto. ${ }^{140}$ In announcing that Miller did not square with its logic,, ${ }^{147}$ Smith inplied that the issuer's conduct in Miller, inducing and carrying out the fraudulent scheme, made him the greater wrongdoer. Such discrepancies are not surprising under the participation test because it is based on the subjective notions of each court.

Another uncertainty in the Smith approach is illustrated in Wells v. Comstock, ${ }^{148}$ where the purchaser, a general manager, was held in pari delicto with the issuing directors even though they mstigated the violation. Although not an officer, plaintiff attended all the ineetings and knew of the director's intention to issue shares to one of the directors for services rendered instead of cash as required by the permit. The plaintiff aided that director in obtaining the shares by arranging a loan to cainouflage the transaction, with the understandimg that these shares were to be held for eventual sale to him. After the shares had been delivered and approximately one-sixth of the purchase price paid, the purchaser refused to perform the remainder of his obligation, claiming that the shares were issued in violation of the permit. ${ }^{140}$ Suit was initiated by the seller who sought to enforce the contract, and the purchaser counterclaimed for rescission. The court denied relief to both parties, holding both parties in pari delicto.

Smith's equal fault analysis, focusing on the greater wrongdoer, might militate in favor of plaintiff's request for rescission on the ground that the plan was devised and instigated by the defendant. But there is the added factor in Wells of an active purchaser who was very close to the decisionmaking process, and some courts might impute a higher degree participation of to him. The recurring defect of the participa-

143. 55 Cal. App. 2d 136, 130 P.2d 740 (1st Dist. 1942).

144. Id. at $144,130 \mathrm{P} .2 \mathrm{~d}$ at 745 .

145. Id. at $145,130 \mathrm{P} .2 \mathrm{~d}$ at 746 .

146. Id. at $145-46,130$ P.2d at 746 .

147. $238 \mathrm{Cal}$. App. 2d at 152, $47 \mathrm{Cal}$. Rptr. at 590.

148. 46 Cal. 2d 528, 297 P.2d 961 (1956).

149. Id. at 531, 297 P.2d at 962 . 
tion test, despite its requirement of a high degree of plaintiff participation, is its reliance on the discretion of each court to decide whether the plaintiff and defendant are equally culpable, because this can cause arbitrary and inconsistent results in the complicated and always different factual patterns that arise in this area.

\section{The Duty Test}

The second California approach for determining in pari delicto, articulated recently in Maner $v$. Mydland, ${ }^{150}$ focuses on the concept of duty in comparing relative culpability. Under this duty test, a purchaser is not considered an equal wrongdoer when he does not himself have the duty to qualify the securities. Although the object is still to determine whether the issuer is the greater wrongdoer, the duty criterion offers an objective and nondiscretionary test.

In Maner, an outside purchaser was told by the directors of a corporation that his written statement of satisfaction was necessary in order to obtain the Commissioner's consent to issue shares. No stateinent was filed, and the trial court concluded that the purchaser's knowing participation in the violation made him in pari delicto. ${ }^{151}$ On appeal the court focused on the directors' ultimate responsibility for obtaining either a permit or the Commissioner's consent. The court concluded that the defendant had the duty to ensure that the sale was made in conformity with the law, ${ }^{152}$ and since he breached it, he was deemed the greater wrongdoer. ${ }^{153}$

In defining those who hold the duty to comply, there can be little doubt Maner equated "issuers" with "directors."154 According to Maner's duty analysis, all purchasers outside the corporation will automatically be granted relief, for there is no way they can be charged

150. 250 Cal. App. 2d 526, 58 Cal. Rptr. 740 (2d Dist. 1967).

151. Id. at 529, 58 Cal. Rptr. at 742 .

152. "It was the duty of the defendant to take the steps necessary to make the sale in conformity with the law." Id. at 531-32, 58 Cal. Rptr. at 743.

153. Id. at 532, 58 Cal. Rptr. at 743 .

154. Maner quoted from a prior California supreme court decision, Bellerue v. Business Files Institute, Inc., 61 Cal. 2d 488, 393 P.2d 401, 39 Cal. Rptr. 201 (1964), which, im cryptic fashion, said that a purchaser who did not become a director until after the purchase could not be in pari delicto:

Although plaintiff subsequently became a director of B.F.I., he was not a

director at the time he and defendants made the agreement, ... Therefore,

he was not in pari delicto with defendants. . . .

Id. at 490-91, 393 P.2d at 402-03, 39 Cal. Rptr. at 202-03, quoted, 250 Cal. App. 2d at $530,58 \mathrm{Cal}$. Rptr. at 743. The plaintiff in Maner did not become a director until two months after the purchase. Id. at 531, 58 Cal. Rptr. at 743 .

Although Maner agrees in result with Hargiss [see note 139 supra], there is a subtle distinction. Maner would deny recovery to any director knowing of and ratifying the issuance, since each director has the duty to comply. Hargiss might have established a higher threshold, given its emphasis on the origimator. 
with responsibility for qualifying the shares. What was a close issue in Smith, where the defendant had the duty to qualify the shares and the plaintiff did not, is straightforward under Maner. Similarly, an officer or employee who aids a director in violating the permit requirements is not in pari delicto with the director due to the director's ultimate duty of compliance. Therefore, the general manager in Wells, who joined the scheine after the directors had already agreed to issue shares in violation of the permit, could obtain rescission under Maner. Furthermore, even an insider who imitiates the transaction with the corporation knowing that the securities are not qualified would not be in pari delicto due to the directors' ultimate duty of compliance. Maner suggests that no amount of participation, short of fraud, by a purchaser who does not have the duty of compliance will result in demal of recovery. While the duty test is still grounded in terms of measuring relative moral worth, the criterion employed is an objective device that eliminates the discretion characteristic of the participation test, thereby avoiding its inconsistent results.

\section{B. The Effect of Applying Perma Life}

Maner's utilization of an objective criterion, which leads to consistency and predictability, does not im itself justify the choice of the duty over the participation test. Both the participation and duty tests are ultimately grounded in the principle that a wrongdoer may not profit from his own wrongdoing. The Perma Life mandate looks to the success of the purchaser's private action in enforcing the policies underlying the qualification requirements, and under this approach both tests should be rejected.

However, the Perma Life enforcement formula achieves results identical to Maner and affords the same advantage of an objective criterion. The identical results are due to a common focus-the issuer's duty. With the enforcement test im mind, the issuer's duty is viewed as a means of achieving enforcement, much in the manner of Pearlstein. ${ }^{155}$ Compliance with the qualification requirements is promoted because the issuer will not easily submit to an eager purchaser who wants to purchase before qualification, knowing that the purchaser is being given a money-back guarantee. And the exception to absolute recovery-a director who purchases in his own illegal stock issueresults from the disservice to enforceinent that would arise from rewarding a culpable purchaser who has the power to effect compliance.

The major hurdle to the adoption of the Perma Life enforcement formula is judicial reluctance to reward a plaintiff who chooses volun-

155. To achieve maximum compliance, the director's duty must be deemed nondelegable; otherwise, the director can easily avoid his responsibilities. 
tarily to forgo the review of the Commissioner. Although Perma Life decided that the public interest in effectuating the statutory policy outweighed a concern for individual equities, ${ }^{156}$ judicial discontent may well manifest itself in efforts to distinguish the California private action from Pearlstein. For example, it might be argued that holding the defendant strictly to his duty should be restricted to a situation in which the private action vindicates a primary purpose not imvolving the investor, as in Pearlstein. ${ }^{157}$ The need to hold the broker to his duty could be considered greater in margin regulation than under a statute designed solely for the protection of the investor. But as the application of Perma Life to $10 \mathrm{~b}-5$ demonstrates, ${ }^{158}$ its mandate cannot be restricted solely to private actions dealing with margin violations. Nathanson-along with the Kuehnert dissent and the Kuehnert majority's logic-deternined that private actions vimdicating public interest in the investor generally must be considered in terms of enforcement. These authorities cannot be distingnished.

Despite resistance that may accompany Perma Life's application to California securities law, the enforcement test produces the same results as one of the two in pari delicto tests presently in effect. ${ }^{159}$ In a sense, then, the application of Perma Life simply resolves the issue of which test to apply. Therefore, Perma Life's ultimate adoption will enable private actions to lend maximum assistance to the statutory goal of compliance with the qualification requirements without producing startling new results. ${ }^{160}$

\section{CONCLUSION}

Perma Life's abolition of the in pari delicto defense in private antitrust actions stems from a general policy that is also pertinent to private securities actions. The judiciary, when dealing with a private action that vindicates the public interest expressed in a regulatory scheme, must come to grips with the Perma Life mandate and its method for achieving enforcement. The doctrine of in pari delicto, even as expressed in the form of equal fault, still adheres to the concept of relative moral worth; it is outdated and should be subsumed under the more inportant enforcement issue.

156. See text accoinpanying notes 31-35 supra.

157. The primary purpose of the margin regulation is to prevent excessive speculation by investors. See note 45 supra.

158. See text accompanying notes 108-15 supra.

159. See note 134 supra.

160. The recognition that the private action should be a means of achieving compliance with the qualification requirements not only resolves the problem of conflicting results; it also guarantees that any deviation from absolute recovery due to exceptional circumstances will be judged in terms of enforcement. This, in turn, assures a higher degree of compliance with the qualification requirements in the future. 
An analysis of Perma Life and the securities cases that have found it to be pertinent reveals a standard approach for determining the consequences of an application of the Perma Life mandate to private actions under different regulatory scheines. First, the question of recovery must be viewed solely in terms of the purposes underlying the regulatory scheme-for example, competition, protection of public investors, or stabilization of the national economy. Second, Perma Life's method for achieving enforceinent-the threat-must be considered; it should be discouraged only when enforcement will not be enhanced. While there is some discretion in the second part of the approach that might occasionally yield different results in the same private action, ${ }^{161}$ discrepancies should be mimimized if recovery is made absolute whenever possible.

Robert K. Schiebelhut

161. For example, consider the subtle differences between Serzysko and Pearlstein and between Kuehnert and Nathanson. 